\title{
Use of Labelled Cisplatin Obtained by Direct Irradiation in a Preliminary Biodistribution Study
}

\author{
Álvaro Dutra de Carvalho Júnior ${ }^{1}$, Fabiana Moreira Abrantes ${ }^{1,2}$, Maria Ângela Menezes ${ }^{2}$, \\ Alexandre Soares Leal ${ }^{2}$, Valbert Nascimento Cardoso ${ }^{3}$ and Mônica Cristina de Oliveira ${ }^{{ }^{*}}$ \\ ${ }^{1}$ Laboratório de Tecnologia Farmacêutica; Departamento de Produtos Farmacêuticos; Faculdade de Farmácia; \\ Universidade Federal de Minas Gerais; Avenida Antônio Carlos, 6627; Pampulha; 31270-901; \\ monica@farmacia.ufmg.br; Belo Horizonte - MG - Brasil. ${ }^{2}$ Serviço de Reator e Irradiações; Centro de \\ Desenvolvimento de Tecnologia Nuclear; CDTN/Comissão Nacional de Energia Nuclear - CNEN; C. P. 941; \\ 30123-970; Belo Horizonte - MG - Brasil. ${ }^{3}$ Laboratório de Radioisótopos; Departamento de Análises Clínicas e \\ Toxicológicas; Faculdade de Farmácia; Universidade Federal de Minas Gerais; Avenida Antônio Carlos, 6627; \\ Pampulha; 31270-901; Belo Horizonte - MG - Brasil
}

\begin{abstract}
This work presents the preparation of radiolabelled cis-dichlorodiammineplatinum (II), CDDP*, from its direct irradiation into a cadmium capsule, using the TRIGA MARK I IPR R-1 research reactor of the CDTN. The ability to detect CDDP* in Ehrlich tumour-bearing mice after administration via an intravenous route was evaluated. After 24 hours, blood and some organs were collected to determine the incorporated activity. The CDDP* showed a great chemical purity and high specific activity that resulted in an optimum in vivo detection. The CDDP* was taken up principally by liver, spleen and kidney. The CDDP* obtained from this condition was shown to be a good tool for biodistribution studies.
\end{abstract}

Key words: Radiolabelled cisplatin, biodistribution, TRIGA research reactor

\section{INTRODUCTION}

Cis-Diamminedichloroplatinum (II) (CDDP) or cisplatin has become one of the most widely used anti-cancer drugs in treating a variety of solid tumors, including testicular, head and neck, ovary and lung tumors (Jakupec et al., 2003; Muggia and Fojo, 2004; Le Chevalier et al., 1994; Guillot et al., 1992). However, its clinical employment has been limited by its toxicity as well as the appearance of resistance (Newman et al., 1999; Deraco et al., 2003; Wernyj and Morin, 2004). The CDDP therapy is particularly restricted by severe nephrotoxicity. It is known that CDDP induces marked focal necrosis in the proximal and distal tubules and damage occurs mainly in the region of the proximal tubule (Singh, G., 1989). Several strategies have been implemented to overcome CDDP related toxicity, such as the synthesis of platinum analogues and the development of new CDDP formulations (Elias et al,, 2003; Harrington et al., 2000). In addition, numerous studies are being carried out in order to elucidate the pharmacokinetics of CDDP, especially its distribution in the kidney, to establish the way to circumvent its toxicity [7-8]. In order to monitor the efficacy and safety of new treatment, it is important to determine the concentration of CDDP

Author for correspondence 
in several organs. For this reason, it is essential to have an adequate analytical method to quantify the CDDP in studies performed in vivo. Atomic absorption spectrometry is frequently employed in this sort of experiment. However, this method requires laborious sample treatment (sample digestion and evaluation of the influence of the matrix of all tissues over the analysis method), and consequently, longer time for the analysis. The employment of labeled compound has been an alternative to the CDDP quantification in biological medium. Sykes et al. (1986) prepared radiolabeled CDDP, CDDP*, by its direct irradiation, but the specific activity was low (< $38.0 \mathrm{kBq} / \mathrm{mg}$ ) and the decomposition of the molecule occurred after 2 hours of bombardment. Thus, CDDP* has been prepared using a cadmium capsule to allow the irradiation of CDDP for a longer time without its degradation. The irradiation was performed at TRIGA MARK I IPR R-1 research reactor. In addition, we were interested in evaluating the detection level of CDDP* after its administration in mice affected by Ehrlich tumour.

\section{MATERIALS AND METHODS}

\section{Irradiation of CDDP}

A sample of CDDP (2.0 mg) was placed inside a cadmium capsule of $1 \mathrm{~mm}$ thickness. It was irradiated in the TRIGA MARK I IPR R-1 reactor, employing an average thermal and epithermal neutron flux of $6.4 \times 10^{11}$ and $4.4 \times 10^{10}$ neutrons. $\mathrm{cm}^{-2} \cdot \mathrm{s}^{-1}$, respectively, at $100 \mathrm{~kW}$. The irradiation time was 8 hours. The chemical purity was determined using high performance liquid chromatography. A $20-\mu \mathrm{L}$ aliquot of CDDP* solution prepared in $0.9 \% \mathrm{w} / \mathrm{v} \mathrm{NaCl}$ solution was injected onto the Lichrospher ${ }^{\circledR} 100 \mathrm{NH} 2$ guard column, 4X4 mm, $5 \mu \mathrm{m}$ (Merck, Darmstadt, Germany) connected to a Lichrospher ${ }^{\circledR} 100 \mathrm{NH} 2$ column, $25 \mathrm{cmX} 4 \mathrm{~mm}, 10 \mu \mathrm{m}$ (Merck, Darmstadt, Germany). The elution was performed with methanol/ethylacetate/N,N-

dimethylformamide/water $4: 4: 1: 1$; the flow rate was of $1.0 \mathrm{~mL} \cdot \mathrm{min}^{-1}$ and the eluate was monitored at $310 \mathrm{~nm}$.

\section{Ehrlich tumour model}

Ehrlich tumor was grown in female Swiss mice. The mice were kept in an area maintained on a standardised light/dark cycle and had free access to food and water. The Ehrlich cell line was kindly supplied by Dr. Jorge Luiz Pesquero (Department of Physiology and Biophysics, Biological Sciences Institute, Federal University of Minas Gerais, Belo Horizonte, MG, Brazil). Tumour cells were inoculated intraperitoneally into mice and the tumor was harvested after eight days. A viable tumor cell suspension was then prepared at a density of $5.0 \times 10^{6}$ cells $/ \mathrm{mL}$. Tumours were transplanted subcutaneously in the right flank of 20-25 g female Swiss mice (Faculty of Pharmacy, Federal University of Minas Gerais, Belo Horizonte, Brazil). Tumours were allowed to grow until all inoculated mice had palpable tumours (20 days postimplantation). All protocols were approved by the ethics committee for animal experiments of the Federal University of Minas Gerais and comply with the guide for the care and use of laboratory animals recommended by Institute of Laboratory Animal Resources.

\section{Biodistribution study}

After 8 hours of irradiation, the CDDP* was allowed to cool for 24 hours inside the TRIGA MARK I IPR R-1 research reactor. The CDDP* obtained was injected by an intravenous route into Ehrlich tumor-bearing Swiss mice $(\mathrm{n}=3)$ at a dose of $4 \mathrm{mg} / \mathrm{kg}$. After 24 hours, the mice were anesthetized with a mixture of xylazine (7.5 $\mathrm{mg} / \mathrm{Kg}$ ) and ketamine $(60 \mathrm{mg} / \mathrm{Kg})$. Blood samples were collected and some organs, such as liver, kidney and spleen were excised. The organs were washed with distilled water, dried with filter paper and weighed. The radioactivity of the organs and blood was measured by an automatic scintillation apparatus covering an energy window of 70-210 or 50-150 keV (ANSR-Abott, USA). The counting times were of 2 and $4 \mathrm{~min}$, respectively, for each energy window. The results were expressed as $\mathrm{cpm} / \mathrm{g}$ of tissue. The data were statistically analyzed by ANOVA.

\section{RESULTS AND DISCUSSION}

By covering the CDDP with a cadmium capsule a higher specific activity (57.0 Bq. $\left.\mathrm{mg}^{-1}\right)$ was obtained than for the bare samples (40.0 Bq. $\mathrm{mg}^{-1}$ ), without the rupture of the molecule, as shown by Leal et al. (in press, Appl. Radiat. Isot.). However, it is important to investigate whether this level of specific activity is sufficient to follow the 
distribution of the drug in vivo. The CDDP* biodistribution results are shown in Fig. 1. The radioactivity was counted using an energy window of $70-210 \mathrm{KeV}$ and $50-150 \mathrm{KeV}$, including or not photopeaks of ${ }^{199} \mathrm{Au}$, respectively. In both cases, the CDDP* was observed to be taken up principally by the spleen, liver and kidneys. The results did not show statistically significative differences in the CDDP uptake between liver and spleen when the radioactivity was determined in the energy window of 70-210 KeV ( $p>0.05$ ).

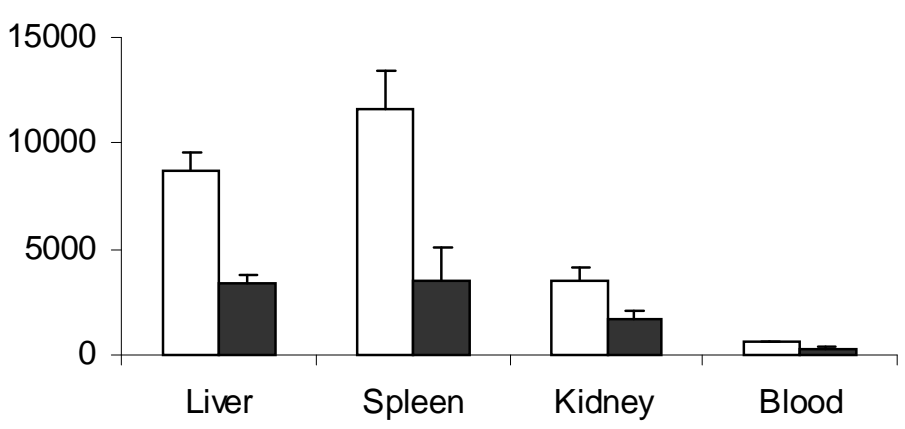

Figure 1 - Biodistribution of CDDP* after 24 hous of its administration in Ehrlich tumour bearing mice and measured at $\square 70-210 \mathrm{keV}$ and $\square 50-150 \mathrm{keV}$. Values are expressed as mean $\pm \mathrm{sd}(\mathrm{n}=3)$.

The same results were observed at $50-150 \mathrm{KeV}$ $(p>0.05)$. On the other hand, the kidney showed an uptake of CDDP* lower than liver for both counting systems. These preliminary results suggest that the quantification of radioactivity in the organs, including the ${ }^{199} \mathrm{Au}$ counting, does not affect the biodistribution of CDDP, and, thus, it would not be necessary to remove this nuclide. Furthermore, the detection of radioactivity with the ${ }^{199} \mathrm{Au}$ inclusion can contribute with a reduction in counting time of each sample, and consequently, it would not be necessary to make the data corrections considering the half-life of the ${ }^{195 \mathrm{~m}} \mathrm{Pt}$. This biodistribution profile is in good agreement with the results obtained by Newman et co-workers (1999), who used graphite furnace atomic absorption spectrophotometry for the CDDP quantification. It leads one to suppose that the radiochemical purity obtained wask satisfactory, such as that obtained by Sykes et al. (1986). In addition, it is noteworthy that the greater specific activity of CDDP allowed optimal radioactivity detection for the performance of biodistribution studies. Certainly, this fact will became more significant when a biodistribution evaluation in a time interval greater than 24 hours is required. Hence, the production of $\mathrm{CDDP}^{*}$ using the cadmium capsule showed it can be a useful tool for the evaluation of the in vivo behavior of new formulations of CDDP.

\section{ACNOWLEDGMENTS}

The authors would like to thank the FAPEMIG, CNEN and CNPq for their financial support. We gratefully acknowledge Dr. Jorge Luiz Pesquero and Quiral Química do Brasil S.A. for providing the Ehrlich cell line and cisplatin, respectively. We are also indebted to the colleagues of the Reactor and Irradiation Service of the CDTN for their cooperation, specially to Zildete Rocha and Amary César for their technical help.

\section{RESUMO}

O presente trabalho refere-se à obtenção de cisdiclorodiaminoplatina (II) radiomarcada, CDDP*, a partir de sua irradiação direta numa cápsula de cádmio. A irradiação foi realizada no reator de pesquisa TRIGA MARK I IPR R-1. Em seguida, foi avaliada a capacidade de detecção da radioatividade emitida por $\mathrm{CDDP}^{*}$ após sua 
administração intravenosa em camundongos acometidos por tumor de Ehrlich. Após 24 horas, fez-se a coleta de amostras de sangue e de alguns órgãos, a fim de se avaliar o nível de radioatividade presente nos mesmos. A CDDP* obtida apresentou uma ótima pureza química e elevada atividade específica que permitiu um excelente nível de detecção. A CDDP*

foi captada principalmente pelo fígado, baço e rins. Portanto, a CDDP* obtida na condição de bombardeamento supracitada mostrou ser uma ferramenta útil para a realização de estudos de biodistribuição.

\section{REFERENCES}

Deraco, M.; Raspagliesi, F. and Kusamura, S. (2003), Management of peritoneal surface component of ovarian cancer. Surg. Oncol. Clin. N. Am., 12, 561-583.

Elias, D. M. and Sideris, L. (2003), Pharmacokinetics of heated intraoperative intraperitoneal oxaliplatin after complete resection of peritoneal carcinomatosis. Sur. Oncol. Clin. N. Am., 12, 755-769.

Guillot, T.; Spielmann, M.; Kac, J.; Luboinski, B.; Tellez-Bernal, E.; Munck, J. N.; Bachouchi, M.; Armand, J. P. and Cvitkovic, E. (1992), Neoadjuvant chemotherapy in multiple synchronous head and neck and esophagus squamous cell carcinomas. Laryngoscope, 102, 311-9.

Harrington, K. J.; Lewanski, C. R. and Stewart, J. S. W. (2000), Liposomes as vehicles for targeted therapy of cancer. Part 2: Clinical development. Clinical Oncology, 12, 16-24.
Jakupec, M. A.; Galanski, M. and Keppler, B. K. (2003), Tumour-inhibiting platinum complexes-state of the art and future perspectives. Rev. Physiol. Biochem. Pharmacol., 146, 1-53.

Le Chevalier, T.; Brisgand, D. and Doulliard, J. Y. (1994), Randomized study of vinorelbine and cisplatin versus vindesine and cisplatin versus vinorelbine alone in advanced non-small-cell lung cancer: results of a European multicenter trial including 612 patients. J. Clin. Oncol., 12, 360-7.

Muggia, F. M. and Fojo, T. (2004), Platinums: extending their therapeutic spectrum. J. Chemother., 16, 77-82.

Newman, M. S.; Colbern, G. T.; Working, P. K.; Engbers, C. and Amantea, M. A. (1999), Comparative pharmacokinetics, tissue distribution, and therapeutic effectiveness of cisplatin encapsulated in long-circulating, pegylated liposomes (SPI-077) in tumor-bearing mice. Cancer Chemothererapy and Pharmacology, 43, 1-7.

Singh, G. (1989), A possible cellular mechanism of cisplatin-induced nephrotoxicity. Toxicology, 58, 71-80.

Sykes, T. R.; Stephens-Newsham, L. G. and Noujaim, A. A. (1986), Reactor production and detection of radiolabeled cis-platinum. Appl. Radiat. Isot., 37, 231-236.

Wernyj, R. P. and Morin, P. J. (2004), Molecular mechanisms of platinum resistance: still searching for the Achilles' heel. Drug Resist Updat., 7, 227-232.

Received: July 12, 2005;

Revised: July 14, 2005; Accepted: August 01, 2005. 